Contents list available at IJRED website

Int. Journal of Renewable Energy Development (IJRED)

Journal homepage: www.ijred.com

\title{
Innovative Green Technology for Sustainable Industrial Estate Development
}

\author{
R. Hadiwijoyo*a, P. Purwanto ab, Sudharto P. Hadiac \\ a Graduate Program on Environmental Studies, Diponegoro University, Semarang, INDONESIA \\ ${ }^{b}$ Department of Chemical Engineering, Diponegoro University, Semarang, INDONESIA \\ c Faculty of Social and Political Sicences, Diponegoro University, Semarang, INDONESIA
}

\section{Article history:}

Received Oct 22, 2012 Received in revised form Jan 1, 2013 Accepted Jan10, 2013 Available online

\begin{abstract}
Sustainable industrial development requires a balance between economic growth, equity and environment. Two major components of industrial development are energy and raw materials. To minimize the environmental impacts of energy and raw materials, important steps are required to deal with the green economy and global warming issues. The use of innovation technology to industrial gas emission is a preventive solution facing global warming. A research has been done in Industrial Estate in Cilegon (IEC) Banten province, Indonesia, to see how to reduce energy demand and encourage uses of more environmentally-friendly energy in the estate. Fossil energy needs in the industrial estate were analyzed to see the opportunities of energy saving and renewable energy development. The target to be achieved is to reduce the greenhouse gas emissions and improve the energy efficiency in the industrial park.
\end{abstract}

Keywords: energy efficiency, innovative technology, sustainable industrial development,

\section{Introduction}

In the beginning of 1960 s, the impact of business activities on the environment was not an important issue. It was due to the fact that exploitation of the environment was not massive and therefore, the damage to the environment was still minor. As stated by Hawken (2005) in line with the continuous growth of the population and the increasing needs for water and energy to support industrial activities, people realized that the availability of natural resources began to run scarce. The continuous and constant needs of the people to exploit the nature for the economic development heralded the natural destruction.

The growth of Indonesian people had increased by 49.6\%, from 147 million in 1980 to 238 million in 2010, with the average growth rate of $1.9 \%$ during the period. With that number of people, Indonesia is a nation with the fourth largest country in the world in terms of population after China, India, and the United States.
Such a population growth will result in the increases of people's living needs such as housing, infrastructures and energy. This will also affect the needs for domestic consumption and exports.

The people's rising consumptive needs that arise due to the population growth may be met by encouraging growth in the production sectors. Such a growth in the supply side could be realized by supporting growth of various industries, especially industries that meet household consumption sectors. Industrial development will definitely require both land spaces for factories and more energy. Presently, the amount of energy in Indonesia is very limited, especially the fossil energy such as oil, natural gas, and coal. To meet the energy need of the production sectors, it requires a considerable amount of energy supply.

Industrial activities are needed to boost economic growth; on the other hand, however, it is the cause of environmental destructions which present negative impacts on the people in the surrounding area.

\footnotetext{
Corresponding author:

E-mail: rohmad01@indo.net.id,purwanto@undip.ac.id
} 
Ultimately, such environmental destructions are responsible for the global warming and climate change. With the worsening environmental condition, a concept of sustainable green development is introduced. The industry is required to contribute to the realization of harmonious and mutually profitable relationship between industrial activities and the environment. Therefore, the emergence of the Eco Industrial Park concept is one of the industrial sector's responses to the global environment change (Fleigh 2000; Lowe 2001).

In the sustainable development principles, all parties are required to be aware of the maintenance of business balance and pollution prevention, plus comprehensive waste management. Natural destructions will occur unless there is a mutual awareness between nature and the people. For example, environmentally-unfriendly business activities such as careless disposals of industrial waste that pollute the environment may bring serious consequences not only to the environment but also to the economy and society.

The economic impact of natural imbalance, namely irresponsible exploitations of raw materials will ultimately affect the natural resources themselves. The high demand for raw materials and the limited availability of such materials will result in rising prices of the raw materials. Besides, inefficient use of energy in industrial processes also contributes to the high cost of production. These two factors - irresponsible exploitation of raw materials and inefficient use of energy - have made an increase in production capacity unable to compete any longer.

In the era of free market, one of the important factors in business is the capability to compete and be efficient in raw materials and energy usage. Pollution prevention, at the beginning of pipe, and right management of industrial waste are more economical than reactive responses. This is so because it is possible to monitor the costs of such preventive activities so that the effects of possible pollution and waste can be well anticipated. According to William Reilly, Director of US EPA (Environmental Protection Agency 1994), the cost of pollution prevention in US in 1994 was almost 1.6\% of the total GDP of US or equal to USD 113 billion. Therefore, the concept of minimizing industrial waste through prevention and waste recycling will be able to lower the overall cost of environmental destruction prevention (US EPA 2011).

The industrial waste here is defined as the material or energy without any economical value and byproducts of a business. It can be of chemical, liquid, gas and solid wastes containing poisonous and hazardous materials. Besides, the residue of fossil energy combustion in the industrial process will create air pollution with high content of $\mathrm{CO}_{2}$. This $\mathrm{CO}_{2}$ pollution will cause the global warming and green house effects if there is not any serious solution taken. The rise of fossil fuel consumption will also increase greenhouse gas emissions such as $\mathrm{CO}_{2}$ (carbon dioxide). Percentage of air pollutants from fuel combustions depends on the fuel sources, and about $75 \%$ of the environmental impact comes from fossil fuel combustions

Pollution and waste are still feasible to control as long as they are still small in amount and number. However, if the waste quantity from a production process is huge it is hard to overcome. Therefore, it calls for a technological innovation as a solution for pollution and industrial waste problems. Moreover, to facilitate monitoring on the efficient use of energy and minimize waste impact on the environment, it requires grouping of industries into clusters or creation of integrated industrial areas. This will enable earlier and simultaneous monitoring on waste management and efficient use of energy, especially energy from fossil fuels, during production processes.

The energy sources used for generating various industrial activities and technology are mostly from the fossil fuels, which create air pollution. The most energy usage for industrial purposes in the $19^{\text {th }}$ century was dominated by fossil fuels, especially coal. Entering the 20th century, energy usage shifted to oil and natural gas. Pollution impacts from oil and gas fuels are relatively lower than that of coal. In September 2002, the sustainable energy utilization and provision system and the green energy usage were stipulated at the World Summit on Sustainable Development in Johannesburg, South Africa.

Fossil fuels come from coal, oil and natural gas. According to Boyle, coal utilization for industrial purposes constitutes almost one fifth of the world's energy usage (Labatt \& White 2007). Combustions originating from coal cause environmental impacts such as air pollution of sulfur $\left(\mathrm{SO}_{2}\right)$, nitrogen $\left(\mathrm{NO}_{2}\right)$ and $\mathrm{H}_{2} \mathrm{~S}$. Besides, coal combustions also yield $\mathrm{CO}_{2}$, methane and mercury. $\mathrm{CO}_{2}$ and methane from the coal combustion contribute the most to the greenhouse gasses.

The second fossil fuel is oil. Although it gives less environmental impact, its availability is limited so that oil energy is no longer competitive to power industries. Oil reserves which are getting scarcer, however, are not an option for a long-term solution to support the cycle of industrial productions (Bank 2007). Natural gas is a clean energy. Energy utilization form the natural gas constitutes a transition in energy usage from the use of coal and oil energy to greener energy utilization. Gas fuels, with their low content of $\mathrm{CO}_{2}$, are relatively clean. The availability of gas fuels, however, is very limited so that it is not a right solution as the sustainable energy either.

Renewable energy is environmental friendly energy and renewable. This means that this energy will not expire. Some of renewable energy is geothermal, biomass, solar energy, wind, water and sea waves. In Indonesia, geothermal has been commercially developed. Indonesia is the third largest country to produce geothermal after the Philippines and the United States. Geothermal energy in Indonesia has the 
potentials to generate about $27,000 \mathrm{MW}$, but only 1,100 MW has been developed. Geothermal is a reliable alternative energy for clean energy campaign. Yet, the problem to develop geothermal energy is the high cost for initial exploration and infrastructure development.

While some of greenhouse gases develop in the atmosphere naturally, other greenhouse gases are present due to human activities. Greenhouse gases that develop naturally are like water vapor, carbon dioxide, methane, oxide, nitrogen and ozone. With human activities that create greenhouse gasses, the level of the greenhouse gas concentration in the atmosphere increases. According to UNFCC, the main greenhouse gases created by human activities are carbon dioxide $\left(\mathrm{CO}_{2}\right)$, methane $\left(\mathrm{CH}_{4}\right)$, nitrogen oxide $\left(\mathrm{N}_{2} \mathrm{O}\right)$, perflouorocarbon (PFCs) and sulfur hexsafloride $\left(\mathrm{SF}_{6}\right)$. According to IPCC, the $\mathrm{CO}_{2}$ concentration in 2001 ranged from 650 to $970 \mathrm{ppm}$, far exceeding the preindustry level $(280 \mathrm{ppm})$. In the last 200 years, there have been more than 2.3 billion tons of $\mathrm{CO}_{2}$ released to the atmosphere as a result of human activities from fossil fuel consumption and changes in land use (US EPA, 2011). Fifty percent of the emission amount was released in a period of 30 years from 1974 to 2004 . According to the report of the World Resources Institute (WRI 2005), the absolute increase of $\mathrm{CO}_{2}$ took place in 2004 with more than 28 billion tons released to atmosphere from the combustions of fossil fuels.

Setting policy and regulation is the principal way for a government to protect the environment. The ultimate objective of government environmental policy is efficiency. There are some instruments that can be used by policy makers to reduce or remove impacts of externalities resulted especially from the use of fossil fuels. According to the Energy Resources International, Inc. (ERC 2006), there are four available instruments to reduce or remove impacts of externalities. The first instrument is voluntary standard, in which there is no enforcement nor penalty for those who does not apply but the party who applies will get benefits. The second instrument is the command and control, a regulation or standard with legal power to reduce emissions according to the emission level required. The third is economic incentives, consisting of emission tax, tradable emission quotas or, called, transferable discharge permit and the deposit-refund program. The forth is technological innovation. With the right technology, the emission waste, especially $\mathrm{CO}_{2}$ waste can be recycled in order to be useful for other products.

The green industrial park is a group of companies/industries that apply clean production technology, process their factory waste and/or take measures to reduce the greenhouse gas emissions at the area where they operate (Fleigh 2000; Lowe 2001). The green industrial park developed by various developers and governments is considered as one example on the applications of the industrial sustainable concept. The things emphasized in the business development are the development of a green industrial park as their competitive excellence in promoting their products (Phyper \& MacLean 2009). According to Khanna (1999), sustainable development will cause a dynamic balance between the function of maintenance (sustainability) and transformation (development) to fulfill the people's living needs. The eco industrial park strategy as part of the sustainable development planning requires right information of the choices of resource utilization, technology, consumption pattern, system structure change, level of the expected living quality and the environment status that guarantees a decrease of ecological pressures by various economic processes.

The social issues in the sustainable community include the community involvement in solving issues related to education, health, intellectual rights, community building, spiritualism, law enforcement for the environment, etc. The sustainable community is closely related to the efforts to develop an eco industrial park, because community involvement is not only limited to their participation in supporting positive industrial activities but also the community themselves are recruited as workers and therefore directly involved in the industry. Even several studies show that industrial development in a region boosts the realization of a sustainable community (Djajadiningrat \& Famiola 2004) .

The Eco Industrial Park (EIP) approach combines two main concepts, that is, how to develop an industrial area with environmental considerations while also still having the capability to create competitive quality products in the market. With the EIP concept, the development of industrial clusters is necessary. It also applies competitive excellence approaches suggested by Porter (1998). The EIP concept emphasizes on the "waste to raw material linkages" concept, i.e. an interaction of information exchange on new innovations of how to manage wastes together and share the infrastructures among industrial players in the cluster. Pollution prevention is a very important basic approach within the industry to develop eco-industrial estate (Bishop 2000; Higgins 1995).

This research was conducted as a follow-up to the recommendations from President Susilo Bambang Yudhoyono during his speech in Copenhagen in December 2009, in which he vowed to cut Indonesia's greenhouse gas emissions by 26 percent by 2020 . Out of the 26 percent, 1.6 percent cut is expected from the reduction of gas waste.

\section{Research Methods}

The research conducted on 61 industrial companies located in the Industrial Estate in Cilegon regency, Banten province, Indonesia to study impacts of their fossil energy usage and uncontrolled consumption of 
raw materials, and also to see the impacts of their $\mathrm{CO}_{2}$ waste. Cilegon is located about $60 \mathrm{~km}$ west of Jakarta.

An Integrated Steel Industry (ISI) located in the industrial area of Industrial Estate in Cilegon (IEC), is one of the 61 industrial companies. IEC classifies companies inside the estate into three industrial businesses, i.e. downstream steel industry, metal fabrication industry, and petro-chemical industry. Substandard applications of environmental management among each category of industries at IEC industrial area have created a significant difference on their compliance to the environmental standards at the estate. On one hand, there is an industry that strictly applies environmental standards at its factory unit. On the other hand, another industry is very loose on the application of the environmental standards. Accumulatively, the environmental quality at IEC industrial area has worsened over time

\section{Result And Discussion}

\subsection{Environmental Impact at Industrial Estate in Cilegon}

Based on the environmental evaluation study data, an important environmental impact present at IEC industrial area is, firstly, the decrease of air quality at IEC. Results of the 2006 air quality monitoring in the City of Cilegon conducted by the Cilegon Municipality's Environmental and Energy Office show that the hydrocarbon and dust levels at several monitoring points exceeded the maximum limit of the air quality standards. From several monitoring points in the City of Cilegon, the record shows that the hydrocarbon (HC) content was greater than acceptable limit.

The second environmental impact present at the IEC industrial area is the decrease of water quality in areas receiving waste from IEC. The 2007 data from the Cilegon Environmental Office show that water quality decreased with indicators exceeding the acceptable water quality standards, including temperature, BOD, COD, ammonia, nitrite, nitrate, phenol, nickel and fluoride. The third environmental impact is the decrease of soil quality receiving the industrial waste or solid waste from the factories of IEC. The fourth impact is the question over the availability of water to fulfill water consumption demand for industrial plants at IEC. Industrial activities at IEC industrial estate need considerable amount of water, among others, for steampowered power plants, plants' cooling systems and domestic needs of each factory.

There are two ideas for designing an eco-conscious industrial area, namely, an efficient use of energy and recycling of production waste. Energy utilization is said to be efficient if a company or an industry knows its real energy needs. Therefore, a symbiosis method on energy usage is an initial method needs to be applied at an industrial area, not only to save energy usage but also reduce $\mathrm{CO}_{2}$ emissions from the energy combustions.

\subsection{Eco-industrial Development}

The ideas for a green industrial development have emerged since 25 years ago. None of them, however, has successfully materialized. Out of 203 industrial areas that have been planned to be developed in Indonesia, only 68 industrial areas are operating so far, most of which are located in Java and Sumatera, especially in Riau Islands Province (Batam), and North Sumatera.

Green Industrial Area Development in Cilegon refers to the success story of the industrial development in Kalundborg, Denmark, one of the world's learning centers for a green industrial area development. The concept of the green industrial area tries to apply a zero emission concept, namely, minimizing the emission of industrial activities to the least possible level by applying the principles of reuse, recycle and reduction at all levels of industrial scales, i.e. small, medium and large industries. This idea will be adjusted to the local spatial management policy, and this industrial development aims to help create a better local spatial policy that meets security, convenient, productive and sustainable criteria.

Results of monitoring at IEC show that production waste in the form of gases had exceeded the acceptable limits applicable in the Cilegon area, including $\mathrm{CO}_{2}$ coming from production process at Steel Factory. The amount of $\mathrm{CO}_{2}$ waste from Steel Factory was 40 tons per hour, coming from the fossil fuel combustion during the production process.

\subsection{Industrial Symbiosis Model at IEC}

To design Eco-Industrial Park at IEC, the process of $\mathrm{CO}_{2}$ purification already implemented. Technology of $\mathrm{CO}_{2}$ purification will absorb $\mathrm{CO}_{2}$ with total 40 Ton/hours from Integrated Steel Industry (ISI). The end product of $\mathrm{CO}_{2}$ will be used for the food and beverage industry, welding company, as well as dry ice for the fishery products.

The following is quality of $\mathrm{CO}_{2}$ emission from steel mill Direct Reduction process at IEC. The quality of emission is subject to the quality of fuel and quality of iron ore used in the Direct Reduction Plant (DR) process. The quantity of emission is about 40 ton/hours, with the composition as shown in Table 1.

Table 1

\begin{tabular}{cc} 
Characteristic of emission & \\
\hline Components & Concentration \\
\hline $\mathrm{CO}_{2}$ & $\max 94.00 \%$ \\
$\mathrm{H}_{2} \mathrm{O}$ & $\max 5.60 \%$ \\
$\mathrm{H}_{2} \mathrm{~S}$ & $\max 0.04 \%$ \\
$\mathrm{~N}_{2}$ & not detected \\
$\mathrm{CH}_{4}$ & not detected \\
$\mathrm{NOx}$ & not detected \\
$\mathrm{SO}_{2}$ & max $700 \mathrm{ppm}$ \\
Other & max $0.36 \%$
\end{tabular}




\subsection{Innovative Technology for $\mathrm{CO}_{2}$ Purification}

$\mathrm{CO}_{2}$ emission from steel mild Direct Reduction plant at IEC is purified to become pure liquide $\mathrm{CO}_{2}$ comply food grade standard utilize for other industial requirement. Process capacity for current process plant is 24,000 Ton/year.

The pressure of the raw $\mathrm{CO}_{2}$ gas at the DR plant is raised in a booster blower before being transferred to a water scrubber at the $\mathrm{CO}_{2}$ process plant. The raw $\mathrm{CO}_{2}$ gas passes the water scrubber in order to cool the gas and remove $\mathrm{SO}_{2}$ from the gas. The water scrubber contains two random packed bed sections. In the bottom section the incoming gas is cooled by recirculated water and the bulk of other water soluble impurities are washed out. In the top section of the process tower, the remaining impurities of $\mathrm{SO}_{2}$ and other water soluble are removed by scrubbing the gas with soda ash solution.

In order to remove $\mathrm{H}_{2} \mathrm{~S}$ the gas runs through a leadlag sulphur filter unit. To reduce the water content of the gas prior to compression, the gas is cooled in a precooler. Cooling for the pre-cooler is supplied by evaporation of liquid refrigerant. A separator drum with a mist eliminator is installed at the outlet of the pre-cooler to separate water condensate from the gas stream.

The $\mathrm{CO}_{2}$ gas is compressed in a two stage compound screw compressor. Compressor lubrication oil is separated from the $\mathrm{CO}_{2}$ gas by means of a two stage coalescing filter system installed downstream of the second compression stage. The compressed gas is cooled in a two stage gas conditioning unit before being dried in the dehydrator. The dehydrator is automatically regenerated by hot ambient air, heated by an external heating system. Cooling of the dehydrator is done by a small stream of purge gas from the $\mathrm{CO}_{2}$ condenser. In addition to drying the gas, the dehydrator will also remove any potential traces of oxygenates such as aldehydes. The dehydrator is followed by an activated carbon filter which will remove any smelling substances from the gas.

In order to ensure the highest possible purity of the $\mathrm{CO}_{2}$ by removal of non condensable gases the plant is supplied with a purification system. The $\mathrm{CO}_{2}$ gas from the activated carbon filter is led through the re-boiler of the purification unit where it is cooled before it continues to the $\mathrm{CO}_{2}$ condenser. The condensate from the $\mathrm{CO}_{2}$ condenser is floating to an intermediate tank and then it is pumped to the top of the purification column, where it counter-flows the stripper gas from the re-boiler through a packed bed in the distillation column. The amount of purge gas is controlled by a $\mathrm{CO}_{2}-$ meter in order to reduce the loss of $\mathrm{CO}_{2}$. Purge gas will be used for instrument air.

The matching refrigerating plant consists of a refrigerant compressor, a $\mathrm{CO}_{2}$ condenser, refrigerant condenser and receiver. The refrigeration plant is designed to maintain a steady pressure at the $\mathrm{CO}_{2}$ gas side in the $\mathrm{CO}_{2}$ condenser. The final product of the $\mathrm{CO}_{2}$ prification process is pure $\mathrm{CO}_{2}$ liquide comply the International food grade standard or ISBT (International Standard Baverrage Technology).

Table 2

Quality of $\mathrm{CO}_{2}$ food grade standard

\begin{tabular}{|c|c|c|}
\hline Component & \multicolumn{2}{|r|}{ Concentration } \\
\hline $\mathrm{CO}_{2}$ & $\min$ & $99.995 \% \mathrm{v} / \mathrm{v}$ \\
\hline $\mathrm{O}_{2}$ & $\max$ & $3 \mathrm{ppm} \mathrm{v/v}$ \\
\hline $\mathrm{H}_{2}$ & $\max$ & $5 \mathrm{ppm} \mathrm{v/v}$ \\
\hline $\mathrm{N}_{2}$ & $\max$ & $5 \mathrm{ppm} \mathrm{v/v}$ \\
\hline Ar dan $\mathrm{He}$ & $\max$ & $65 \mathrm{ppm} \mathrm{v} / \mathrm{v}$ \\
\hline $\mathrm{CO}$ & $\max$ & $2 \mathrm{ppm} \mathrm{v} / \mathrm{v}$ \\
\hline NO & $\max$ & $2.5 \mathrm{ppm} \mathrm{v} / \mathrm{v}$ \\
\hline $\mathrm{NO}_{2}$ & $\max$ & $2.5 \mathrm{ppm} \mathrm{v/v}$ \\
\hline $\mathrm{SO}_{2}$ & $\max$ & $1 \mathrm{ppm} \mathrm{v/v}$ \\
\hline $\mathrm{H}_{2} \mathrm{~S}$ & $\max$ & $0.1 \mathrm{ppm} \mathrm{v} / \mathrm{v}$ \\
\hline $\cos$ & $\max$ & $0.1 \mathrm{ppm} \mathrm{v/v}$ \\
\hline $\mathrm{NH}_{3}$ & $\max$ & $2.5 \mathrm{ppm} \mathrm{v/v}$ \\
\hline PH3 & $\max$ & $0.3 \mathrm{ppm} \mathrm{v} / \mathrm{v}$ \\
\hline Total $\mathrm{C}_{\mathrm{x}} \mathrm{H}_{\mathrm{y}}\left(\mathrm{as} \mathrm{CH}_{4}\right)$ & $\max$ & $10 \mathrm{ppm} \mathrm{v} / \mathrm{v}$ \\
\hline Condensable $\mathrm{C}_{x} \mathrm{H}_{\mathrm{y}}$ & $\max$ & $5 \mathrm{ppm} \mathrm{v/v}$ \\
\hline Acetaldehyde & $\max$ & $0.2 \mathrm{ppm} \mathrm{v/v}$ \\
\hline Alcohols & $\max$ & $1 \mathrm{ppm} \mathrm{v/v}$ \\
\hline Other volatile oxygenates & $\max$ & $1 \mathrm{ppm} \mathrm{v/v}$ \\
\hline Benzene & $\max$ & $0.02 \mathrm{ppm} \mathrm{v/v}$ \\
\hline $\mathrm{H}_{2} \mathrm{O}$ & $\max$ & $10 \mathrm{ppm} \mathrm{v/v}$ \\
\hline Taste and Odour & no fo & ign taste/odour \\
\hline
\end{tabular}

The final product as is pure $\mathrm{CO}_{2}$ liquide could be utilize for carbonized beverage; preservation food industries such as ice cream, meat, and vegetables; fishery industries such cool storage and transportation chillers; construction /manufacturing industries such welding and testing; oil and gas production such as; secondary recovery for deflated oil wells; fumigation granular storage, tobacco storage; chemical Industrial process; bleaching process for pulp industries; and metal cold blasting / cleaning near white metal.

\section{Conclusions}

The conclusion of this study is stated as follows. To boost economic growth, it requires sustainable industrial development in various sectors. To develop robust industries, it requires explorations of raw materials and energy. Explorations of raw materials, however, cause environmental and social impacts, while usage of energy resources, especially fossil energy, causes $\mathrm{CO}_{2}$ waste emission. The $\mathrm{CO}_{2}$ waste is currently the largest contributor to the greenhouse gas emissions. Several solutions to create a green economy are available, among others, managing industries in clusters in an industrial estate. By placing these industries in one location, it is easier to monitor their raw material usage, energy consumption level and waste management. A controlled raw material utilization and efficient fossil energy usage by industries are voluntary preventive measures. In the case that $\mathrm{CO}_{2}$ waste is still emitted from an industrial estate, available green technology or an environmentally-friendly technology 
Citation: Hadiwijoyo, R., Purwanto \& Sudharto P. Hadi (2013) Innovative Green Technology for Sustainable Industrial Estate Development. Int. Journal of Renewable Energy Development, 2(1), 53-58

$\mathrm{P}$ a g e $\mathbf{5 8}$

can be implemented to process $\mathrm{CO}_{2}$ waste present in the estate.

\section{References}

Bank, F.E. (2007) The Political Economy of World Energy, Word Scientific Publishin Co,Pte, Ltd, Singapore.

Bishop, P.L. (2000) Pollution Prevention: Fundamentals and Practice. The McGrow-Hill Companies, USA.

Djajadiningrat, S.T., Famiola, M. (2004) Kawasan Industri Berwawasan Lingkungan. Rekayasa Sains, Bandung.

ERC (Energy Resources International, Inc) (2006) Report on Participation by Developing/Transitional Countries.

Fleig, A. (2000) Eco-Industrial Parks, A Strategy toward Industrial ecology in Developing and Newly Industrialized Countries, GTZ.

Hawken, P. (2005) The Ecology of Commerce: A Declaration of Sustainability. HarperCollins Publishers, Inc. New York.
Higgins, T.E. (1995) Pollution Prevention Handbook, Lewis Publisher, Boca Raton.

Khanna, P., Ram Babu, P., George, M.S. (1999) Progress in Planning Journal 52, 101-166.

Labatt, S. and White, R.R. (2007) Carbon Finance, The Financial Implications of Climate Change. Published by John Wiley \& Sons, Inc. Hoboken, New Jersey.

Lowe, E.A. (2001) Eco Industrial Park Handbook for Asian Developing Countries. Indigo Development, Oakland.

Phyper, J.D. \& MacLean, P. (2009) Good To Green, Managing Business Risks and Opportunities in the Age of Environmental Awareness. John Wiley \& Sons Canada, Ltd, Ontario.

Porter, M.E. (1998) On Competition, Harvard University Business School Press.

US EPA (2011) US Environmental Protection Agency. www.epa.gov, accessed July 4

WRI (2005) WRI Annual Report, http://pdf.wri.org/ wri_annualreport_2005.pdf, accessed July 4, 2011. 